\title{
EFFECT OF GIBBERELLIC ACID SPRAYING AND SOAKING OF RHIZOMES ON THE GROWTH AND FLOWERING OF CALLA LILY (Zantedeschia SPRENG.)
}

\author{
Beata Janowska1, Roman Andrzejak² \\ ${ }^{1}$ Department of Ornamental Plants \\ ${ }^{2}$ Chair of Phytopathology, University of Life Sciences in Poznań, Dąbrowskiego 159, 60-594 Poznań \\ e-mail: beataj@up.poznan.pl
}

Received: 15.05 .2010

\section{Abstract}

Rhizomes of Zantedeschia, 15-18 cm in circumference with leaf buds $0.5-1 \mathrm{~cm}$ in length, were planted into $20-\mathrm{cm}$ pots on 15 May 2006 into a medium consisting of peat with a $\mathrm{pH}$ of 6.2, enriched with a slow-release fertiliser Osmocote Plus (3-4M) and mixed with fresh shredded pine bark at a rate of 3:1 (v:v). Before planting, the rhizomes were soaked for 20 minutes in a water solution of gibberellic acid at a concentration of 150 $\mathrm{mg} \times \mathrm{dm}^{-3}$, or sprayed with the same concentration once, twice or three times, each time after thorough drying. For each round of spraying, $100 \mathrm{ml}$ of the solution were used. Gibrescol $10 \mathrm{MG}$ was applied. Gibberellic acid had a similar effect, whether applied in the form of a solution for soaking or spraying of rhizomes. The number of sprayings of rhizomes had no effect on the effectiveness of gibberellic acid. In the cultivar 'Black Magic', rhizome spraying caused earlier flowering, while in 'Cameo' a similar effect was obtained by soaking the rhizomes in gibberellic acid. Gibberellic acid had no effect on the quality of flowers and the number of leaves. Gibberellic acid had a good effect on the index of leaf greenness in the cultivars under study.

Key words: Zantedeschia, gibberellic acid, spraying and soaking of rhizomes, yield, quality, flowers, leaves

\section{INTRODUCTION}

The research on growth regulators carried out in the world is intended to improve the quality of plants, boost flower crops and reduce production costs. An ever-wider use is made of gibberellic acid, and its usefulness in the cultivation of many species of ornamental plants has been studied for more than a decade. In the case of geophytes, its effectiveness has been proved in, e.g., hyacinths, grape-hyacinths, cyclamens and tulips (S a n i e w s ki and Pu chalski, 1977; S a niew ski et al. 1978; Krause and B orejs z a - Wy s ocki, 1981; Now ak and Rudni- c k i , 1993; Treder et al. 1999, N o w a k, 2000). It also brings good results in growing many species of the Araceae family by stimulating the development of flowers (F u n nell and T j i a, 1988; He n n y, 1989; Corr and Widmer; 1991, Dennis et al. 1994; J a n o w s ka and Krause, 2001; J a n ow ska and $\mathrm{S}$ chroeter, 2002). Gibberellic acid is also efficient in the cultivation of calla lilies with colourful spathes (Harbaugh and Wilfret, 1979, Henny, 1981 and 1983, He n n y and N orm a n, 1999). However, the soaking of rhizomes generally applied in this species is not recommendable in phytosanitary terms, hence other methods of gibberellic acid application should be sought that would be equally efficient as the soaking of rhizomes, while protecting the plants against the spread of bacterial diseases.

The aim of this study was to assess the effect of rhizome spraying with gibberellic acid on the growth and flowering of Zantedeschia cultivars with colourful spathes.

\section{MATERIAL AND METHODS}

The cultivars used in the study were 'Cameo', derived from Zantedeschia albomaculata /Hook./ Baill., and 'Black Magic' coming from an inter-species hybrid of Zantedeschia elliottiana /W. Wats./ Engl. $\mathrm{x}$ Z. macrocarpa Engl.

Rhizomes $15-18 \mathrm{~cm}$ in circumference with leaf buds $0.5-1 \mathrm{~cm}$ in length were planted into $20-\mathrm{cm}$ pots on 15 May 2006 into a medium consisting of peat with a $\mathrm{pH}$ of 6.2, enriched with a slow-release fertiliser Osmocote Plus (3-4M) and mixed with fresh shredded pine bark at a rate of 3:1 (v:v). Before planting, the rhizomes were soaked for 20 minutes in a water solution of gibberellic acid at a concentration of $150 \mathrm{mg} \times \mathrm{dm}^{-3}$, or sprayed 
with the same concentration once, twice or three times, each time after thorough drying. For each round of spraying, $100 \mathrm{ml}$ of the solution were used. Gibrescol $10 \mathrm{MG}$ was applied, a preparation in the form of microgranules readily dissolving in water that contains $10 \%$ of gibberellic acid. Control - dry rhizomes.

The experiment consisted of 10 treatments (cultivar x mode of rhizome treatment). Each treatment involved 5 plants in 3 replications.

The plants, grown in a plastic tunnel, were fed starting with the fifth week of cultivation. Every 10-14 days, solutions of mixed fertilisers, Peters Professional and brown Superba, were applied at a concentration of $0.2 \%$. At the start of vegetation, when the leaves were fully developed, lime saltpetre at a concentration of $0.2 \%$ was foliar applied once.

The earliness of flowering was determined using the weighted mean of days from the planting of rhizomes to the flowering of plants, as well as the volume of crop, peduncle and spathe length, and flower weight. The number of leaves growing from a single rhizome was calculated, as well as the index of leaf greenness correlated with chlorophyll content, for which a chlorophyll meter SPAD-502 was used (Gre g o r c z y k and Raczyńska, 1997; Gregorczyk et al. 1998).

The results were processed statistically by means of analysis of variance using Duncan's test for the grouping of means at the $\alpha=0.05$ significance level.

\section{RESULTS}

When comparing the earliness of flowering of the cultivars, 'Black Magic' was found to bloom a bit earlier only in the combination where gibberellic acid had been applied to their rhizomes in the form of a one-time spraying solution, and in 'Cameo', when the rhizomes were soaked or sprayed three times with it. A slight delay in flowering was only recorded in the cultivar 'Cameo' in the combination where the rhizomes were sprayed with gibberellic acid twice (Table 1).

Table 1

Earliness of Zantedeschia flowering depending on the variant of gibberellic acid application and on the cultivar

\begin{tabular}{|c|c|c|c|c|c|}
\hline \multirow{3}{*}{ Cultivar } & \multicolumn{5}{|c|}{$\begin{array}{l}\text { Variant of } \mathrm{GA}_{3} \text { application } \\
\qquad\left(150 \mathrm{mg} \times \mathrm{dm}^{-3}\right)\end{array}$} \\
\hline & \multirow{2}{*}{ dry rhizomes } & \multirow{2}{*}{$\begin{array}{l}\text { rhizomes soaked } \\
\text { in } \mathrm{GA}_{3}\end{array}$} & \multicolumn{3}{|c|}{ rhizomes sprayed with $\mathrm{GA}_{3}$} \\
\hline & & & once & twice & 3 times \\
\hline Black Magic & 50 & 50 & 46 & 50 & 49 \\
\hline Cameo & 48 & 43 & 49 & 53 & 43 \\
\hline
\end{tabular}

The yield of cut flowers of the cultivars under study significantly depended on both the variant of $\mathrm{GA}_{3}$ application and the cultivar (Table 2). Irrespective of the variant, 'Black Magic' flowered more abundantly, with a mean of 3.4 flowers per rhizome. The yield was observed to have increased after the application of gibberellic acid in the form of both the rhizome-soaking and rhizome-spraying solution. No differences were recorded between the modes of $\mathrm{GA}_{3}$ application.

When comparing the length of peduncles, this feature was found to depend significantly on the cultivar only (Table 2). Significantly longer peduncles, irrespective of the variant of $\mathrm{GA}_{3}$ application, were developed by the cultivar 'Black Magic', while in 'Cameo' peduncle length depended significantly on the variant of $\mathrm{GA}_{3}$ application. The effect produced in this cultivar by the soaking or spraying of rhizomes with $\mathrm{GA}_{3}$ was flowers with peduncles shorter than in the control. The differences were substantial and ranged from 7.5 to $10.5 \mathrm{~cm}$.

The length of the spathe significantly depended on the cultivar only (Table 2). Irrespective of the variant of $\mathrm{GA}_{3}$ application, 'Cameo' developed spathes shorter by an average of $2.2 \mathrm{~cm}$.

When comparing flower weight, it was found that this parameter significantly depended on the cultivar only (Table 2). Flowers with a significantly smaller weight developed in the cultivar 'Cameo'.

The number of leaves growing from a single rhizome depended significantly on the cultivar only (Table 3). Irrespective of the $\mathrm{GA}_{3}$ variant employed, 'Black Magic' developed more abundant leaves, three times as many on average as 'Cameo'. 
Table 2

Size and quality of Zantedeschia yield depending on the variant of gibberellic acid application and on the cultivar

\begin{tabular}{|c|c|c|c|c|c|c|}
\hline \multirow{3}{*}{ Cultivar } & \multicolumn{5}{|c|}{ Variant of $\mathrm{GA}_{3}$ application $\left(150 \mathrm{mg} \times \mathrm{dm}^{-3}\right)$} & \multirow{3}{*}{ Mean } \\
\hline & \multirow{2}{*}{ dry rhizomes } & \multirow{2}{*}{$\begin{array}{c}\text { rhizomes } \\
\text { soaked in } \mathrm{GA}_{3}\end{array}$} & \multicolumn{3}{|c|}{ rhizomes sprayed with $\mathrm{GA}_{3}$} & \\
\hline & & & once & twice & 3 times & \\
\hline \multicolumn{7}{|c|}{ Yield of cut flowers } \\
\hline Black Magic & $2.4 b^{*}$ & $3.7 \mathrm{cb}$ & $3.6 \mathrm{c}$ & $3.8 \mathrm{c}$ & $3.7 \mathrm{c}$ & $3.4 \mathrm{~b}$ \\
\hline Cameo & $1.2 \mathrm{a}$ & $2.7 \mathrm{~b}$ & $3.0 \mathrm{~b}$ & $2.7 \mathrm{~b}$ & $2.8 \mathrm{~b}$ & $2.7 \mathrm{a}$ \\
\hline Mean & $1.8 \mathrm{a}$ & $3.2 \mathrm{~b}$ & $3.3 \mathrm{~b}$ & $3.2 \mathrm{~b}$ & $3.2 \mathrm{~b}$ & \\
\hline \multicolumn{7}{|c|}{ Length of peduncle $(\mathrm{cm})$} \\
\hline Black Magic & $47.8 \mathrm{c}$ & $51.0 \mathrm{c}$ & $53.9 \mathrm{c}$ & $50.0 \mathrm{c}$ & $51.6 \mathrm{c}$ & $50.8 \mathrm{~b}$ \\
\hline Cameo & $35.4 \mathrm{~b}$ & $24.9 \mathrm{a}$ & $27.9 \mathrm{a}$ & $27.3 \mathrm{a}$ & $27.8 \mathrm{a}$ & $28.7 \mathrm{a}$ \\
\hline Mean & $41.6 \mathrm{a}$ & $37.9 \mathrm{a}$ & $40.9 \mathrm{a}$ & $38.6 \mathrm{a}$ & 39.7 a & \\
\hline \multicolumn{7}{|c|}{ Length of spathe $(\mathrm{cm})$} \\
\hline Black Magic & $11.9 \mathrm{~b}$ & $12.2 \mathrm{~b}$ & $12.4 \mathrm{~b}$ & $12.3 \mathrm{~b}$ & $12.5 \mathrm{~b}$ & $12.3 \mathrm{~b}$ \\
\hline Cameo & $10.2 \mathrm{a}$ & $9.7 \mathrm{a}$ & $10.3 \mathrm{a}$ & $10.1 \mathrm{a}$ & $10.2 \mathrm{a}$ & $10.1 \mathrm{a}$ \\
\hline Mean & $11.1 \mathrm{a}$ & $11.0 \mathrm{a}$ & $11.4 \mathrm{a}$ & $11.1 \mathrm{a}$ & $11.3 \mathrm{a}$ & \\
\hline \multicolumn{7}{|c|}{ Flower weight (g) } \\
\hline Black Magic & $21.1 \mathrm{ab}$ & $27.8 \mathrm{~cd}$ & $31.4 \mathrm{~d}$ & $27.4 \mathrm{~cd}$ & $28.6 \mathrm{~cd}$ & $27.3 \mathrm{~b}$ \\
\hline Cameo & $24.1 \mathrm{bc}$ & $15.1 \mathrm{a}$ & $20.6 \mathrm{ab}$ & $16.9 \mathrm{a}$ & $16.8 \mathrm{a}$ & $18.7 \mathrm{a}$ \\
\hline Mean & $22.6 \mathrm{a}$ & $21.5 \mathrm{a}$ & $26.0 \mathrm{a}$ & $22.2 \mathrm{a}$ & $22.7 \mathrm{a}$ & \\
\hline
\end{tabular}

*Means followed by the same letter do not differ significantly at the $\alpha=0.05$ level

Table 3

Number of Zantedeschia leaves and the index of their greenness (SPAD) depending on the variant of gibberellic acid application and on the cultivar

\begin{tabular}{|c|c|c|c|c|c|c|}
\hline \multirow{3}{*}{ Cultivar } & \multicolumn{5}{|c|}{ Variant of $\mathrm{GA}_{3}$ application $\left(150 \mathrm{mg} \times \mathrm{dm}^{-3}\right)$} & \multirow{3}{*}{ Mean } \\
\hline & \multirow{2}{*}{ dry rhizomes } & \multirow{2}{*}{$\begin{array}{l}\text { rhizomes soaked } \\
\text { in } \mathrm{GA}_{3}\end{array}$} & \multicolumn{3}{|c|}{ rhizomes sprayed with $\mathrm{GA}_{3}$} & \\
\hline & & & once & twice & 3 times & \\
\hline \multicolumn{7}{|c|}{ Number of leaves } \\
\hline Black Magic & $20.4 \mathrm{c}^{*}$ & $19.4 \mathrm{bc}$ & $20.1 \mathrm{bc}$ & $16.1 \mathrm{~b}$ & $17.6 \mathrm{bc}$ & $18.7 \mathrm{~b}$ \\
\hline Cameo & $7.2 \mathrm{a}$ & $8.4 \mathrm{a}$ & $8.2 \mathrm{a}$ & $8.5 \mathrm{a}$ & $7.0 \mathrm{a}$ & $7.8 \mathrm{a}$ \\
\hline Mean & $13.8 \mathrm{a}$ & $13.9 \mathrm{a}$ & $14.1 \mathrm{a}$ & $12.3 \mathrm{a}$ & $12.3 \mathrm{a}$ & \\
\hline \multicolumn{7}{|c|}{ Index of leaf greenness } \\
\hline Black Magic & $60.1 \mathrm{~b}$ & $65.7 \mathrm{c}$ & $64.1 \mathrm{c}$ & $63.0 \mathrm{c}$ & $65.8 \mathrm{c}$ & $63.7 \mathrm{~b}$ \\
\hline Cameo & $50.5 \mathrm{a}$ & $53.7 \mathrm{~b}$ & $53.3 \mathrm{~b}$ & $55.8 \mathrm{~b}$ & $58.8 \mathrm{~b}$ & $54.4 \mathrm{a}$ \\
\hline Mean & $55.3 \mathrm{a}$ & $59.7 \mathrm{~b}$ & $58.7 \mathrm{~b}$ & $59.4 \mathrm{~b}$ & $62.3 \mathrm{~b}$ & \\
\hline
\end{tabular}

*Means followed by the same letter do not differ significantly at the $\alpha=0.05$ level 
The index of leaf greenness depended significantly on both the cultivar and the variant of $\mathrm{GA}_{3}$ application (Table 3). Irrespective of the cultivar, the lowest index was recorded in the leaves of the control plants. The use of gibberellic acid for spraying and soaking of rhizomes resulted in a significantly more intensive leaf colour. Irrespective of the variant of $\mathrm{GA}_{3}$ application, a significantly higher index of leaf greenness was observed in 'Black Magic'.

\section{DISCUSSION}

The discovery of natural growth regulators has opened up new possibilities of regulation of plant yield, growth, and development. In the case of Zantedeschia with colourful spathes, the application of gibberellin acid has greatly improved their flowering, thereby making them much more attractive to producers, who can thus offset the substantial costs of the purchase of rhizomes.

The research to improve the yield of Zantedeschia with colourful spathes has been carried out for about 20 years. Studies initiated by foreign researchers have failed to establish an optimum concentration of gibberellic acid used in the form of a solution for soaking rhizomes. Recommendations speak of the application of $\mathrm{GA}_{3}$ at concentrations of 50 to $500 \mathrm{mg} \times$ $\mathrm{dm}^{-3}$ (Funnell and Tjia, 1988; Dennis et al., 1994; C o r r and W i d m e r, 1999). The research carried out in Poland has made it possible to narrow down the optimum concentrations of gibberellic acid to 100$150 \mathrm{mg} \times \mathrm{dm}^{-3}$ (J anowska and Krause, 2001; Janowska and Schroeter, 2002, Janowska and $\mathrm{Zakrze}$ w s k i, 2006), hence in the present work gibberellic acid applied for spraying and soaking of rhizomes had a concentration of $150 \mathrm{mg} \times \mathrm{dm}^{-3}$.

Soaking rhizomes before planting is a simple practice to perform, but unfortunately the rhizomesoaking solution is a carrier of bacteria, especially very dangerous Erwinia carotovora ssbp. carotovora responsible for a disease fatal to Zantedeschia - soft rot of rhizomes. Hence it is necessary to seek other methods allowing a safe use of gibberellic acid. J a n ow sk a and Zakrzewski (2006) compared the efficiency of foliar sprays with gibberellic acid at a concentration of $150 \mathrm{mg} \times \mathrm{dm}^{-3}$ with that of rhizome soaking in three Zantedeschia cultivars. In both methods, their flowering was more abundant, but soaking the rhizomes in gibberellic acid proved much more effective. In the present experiment, apart from soaking the rhizomes in a water solution of gibberellic acid, this growth regulator was also used for spraying. It was demonstrated that irrespective of the variant of $\mathrm{GA}_{3}$ application, the yield of cultivars 'Black Magic' and 'Cameo' had increased, and what is highly significant, the effectiveness of the acid in all the variants was similar. This good result suggests that rather than being soaked in gibberellic acid, rhizomes can be sprayed with it, which is a far safer practice eliminating the possibility of bacterial transfer, and less time-consuming too.

When comparing the earliness of flowering of the cultivars, it was found that in 'Black Magic' it was the spraying of the rhizomes with gibberellic acid that caused its earlier flowering, while in 'Cameo' a similar effect was obtained by soaking the rhizomes. This is in contradiction to the results reported by J a now ska and Schroeter (2002), when the use of gibberellic acid caused a delay in the flowering of Zantedeschia by 3-4 weeks. A similar pattern was followed by the cultivars 'Pink Persuasion' and 'Sensation', which bloomed several days later (J a n ow ska and $\mathrm{Kr}$ a u s e, 2001). A later entry into the period of flowering after the application of gibberellic acid was also reported by Treder (2003b) in the cultivars 'Black Magic' and 'Mango'. In turn, Funnell and Tjia (1988) obtained an earlier flowering of Zantedeschia treated with gibberellic acid.

The present research showed that the qualitative features of flowers, as expressed by the length of the peduncle and spathe as well as flower weight, significantly depended on the cultivar only. Much longer peduncles and more sizeable spathes were developed by the cultivar 'Black Magic'. Hence, its flower weight also was greater than in 'Cameo'. As follows from literature reports, the response of plants to gibberellic acid can vary depending on the cultivar and mode of application. Janowska and $\mathrm{Zakrzewski}$ (2006) demonstrated that in the cultivars 'Black Eyed Beauty' and 'Cameo' the flowers which had grown from rhizomes soaked in gibberellic acid had the longest peduncles, and in 'Treasure', the shortest. In turn, foliar-sprayed gibberellic acid caused the formation of longer spathes only in 'Cameo'. In 'Treasure' gibberellic acid used for both rhizome soaking and foliar spraying produced the development of flowers with shorter spathes. When comparing flower weight, the authors found that after the application of gibberellic acid the cultivar 'Cameo' had flowers with the greatest weight, and 'Treasure' with the smallest. Treder (2003a) claims that an increase in the yield of Zantedeschia goes with flowers having shorter peduncles. This was corroborated by J a now ska and S chroeter (2002), who reported that in the cultivar 'Black Magic' an increase in the crop of flowers as a result of $\mathrm{GA}_{3}$ application was accompanied by a shortening of peduncles. This regularity was not confirmed by $\mathrm{J}$ a n ow s k a and Krause (2001) in the cultivars 'Sensation' and 'Pink Persuasion'. T r e d e r (2003b) failed to find any effect of gibberellic acid on flower weight, but he did confirm the development of shorter peduncles in 
the cultivar 'Mango'. As D e n n i s et al. (1994) claim, however, after the application of gibberellic acid at a concentration of $25 \mathrm{mg} \times \mathrm{dm}^{-3}$ the quality of Zantedeschia flowers was better.

When comparing the number of leaves and the index of their greenness, it was found that the number of leaves growing from rhizomes depended solely on the cultivar. The cultivar with more abundant leaves was 'Black Magic'. However, the application of gibberellic acid boosted the index of leaf greenness. It appears from the research by $\mathrm{J}$ a now s ka and $\mathrm{Za}$ k r z e w s k i (2006) that only in 'Cameo' fewer leaves grew from rhizomes soaked in gibberellic acid in the second year of study. In turn, when applied for rhizome soaking, this regulator improved the intensity of leaf greenness in 'Cameo' in the first year of study and in 'Treasure' in both years. On the basis of the intensity of colour in freesia leaves, My net t et al. (2001) found that plants grown from bulbs soaked in gibberellic acid had a significantly higher index of leaf greenness, which shows its role to be stimulating. As Cor r and Wi d mer (1991) report, in Zantedeschia rehmannii the number of leaves developing from rhizomes largely depends on their size rather than on treatment with gibberellic acid. Similarly J e r z y and J a n ow ska (2003) state that gibberellic acid does not affect the number of leaves in Zantedeschia with colourful spathes.

\section{CONCLUSIONS}

1. Gibberellic acid had a similar effect, whether applied in the form of a solution for soaking or spraying of rhizomes.

2. The number of sprayings of rhizomes had no effect on the effectiveness of gibberellic acid.

3. In the cultivar 'Black Magic', rhizome spraying caused earlier flowering, while in 'Cameo' a similar effect was obtained by soaking the rhizomes in gibberellic acid.

4. Gibberellic acid had no effect on the quality of flowers and the number of leaves.

5. Gibberellic acid had a good effect on the index of leaf greenness in the cultivars under study.

\section{REFERENCES}

Corr B. E., Wid mer R. E., 1991. Paclobutrazol, gibberellic acid and rhizome size affect growth and flowering of Zantedeschia. HortScience, 26 (2): 133-135.

Dennis D., Doreen D. J., Ohteki T., 1994. Effect of a gibberellic acid 'quick-dip' and storage on the yield and quality of blooms from hybrid Zantedeschia tubers. Sci. Hortic. 57: 133-142.

Funnel1 K. A., Tji a B. O., 1988. Effect of storage temperature, duration and gibberellic acid on the flowering of Zantedeschia elliottiana and Z. 'Pink Satin'. J. Am. Soc. Hortic. Sci. 113 (6): 860-863.

Gregorczyk A., Raczyńska A., 1997. Study of a correlation between Arnon's method and measurements of the chlorophyll content using a chlorophyll meter. Folia Univ. Agric. Stetin. 181, Agricult. 5: 119-123 (in Polish).

Gregorczyk A., Raczyńska A., Pacewicz K., 1998. Analysis of the standard curves of chlorophyll content for the basic grainspecies. Biul. Magnezol. 3 (1): 19-24 (in Polish).

Harbaugh B. J., Wilfret G. J., 1979. Gibberellic acid stimulates flowering in Caladium hortulanum Birdsey. Hort Science, 14 (1): 72-73.

Hen n y R. J., 1981. Promotion of flowering in Spathiphyllum 'Mauna Loa' with gibberellic acid. HortScience 16: 554-555.

Henny R. J., 1983. Flowering of Aglaonema commutatum 'Treubii' following treatment with gibberellic acid. HortScience, 18 (3): 374.

Hen ny R. J., 1989. Floral Induction in 2n and 4n Dieffenbachia maculata 'Perfection' after treatment with gibberellic acid. HortScience, 24 (2): 307-308.

Hen ny R. J., Norman D. J., 1999. Gibberellic acid-induced flowering of Syngonium podophyllum Schott 'White Butterfly'. HortScience, 34 (4): 676-677.

J a now sk a B., K ra u se J., 2001. The influences of tuber treatment by gibberellic acid on the flowering of Zantedeschia. Rocz. AR Pozn. CCCXXXII, Ogrodn. 33: 61-67 (in Polish).

J a nowska B., Schroeter A., 2002. The influences of gibberellic acid on flowering of Zantedeschia elliottiana /W. Wats./ Engl. 'Black Magic'. Zesz. Probl. Post. Nauk Roln. 483: 93-99 (in Polish).

Janowska B., Zakrzewski P., 2006. The effect of gibbberellic acid and rhizome treatment on flowering of calla lily (Zantedeschia Spreng.). Zesz. Probl. Post. Nauk Roln. cz. I, 510: 223-233 (in Polish).

Jerzy M., Janowska B., 2003. Growth and flowering of Zantedeschia elliottiana /W. Wats./ Engl. cultivated from cutting treated in vitro with gibberellic acid. Zesz. Probl. Post. Nauk Roln. 491: 125-130 (in Polish).

Krause J., Borejsza-Wysocki W., 1981. The effect of cooling bulbs by length of the period and applying the date of gibberellic acid of the growth and flowering of tulips. Prace Komisji Nauk Rolniczych i Komisji Nauk Leśnych, LI: 161-168 (in Polish).

Mynett K., Startek L., Żurawik P., Płoszaj B., 2001. The effect of Gibrescol and Flordimex on the emergence and growth of freesia. Rocz. AR w Poznaniu CCCXXXII, Ogrodn. 33: 103-110 (in Polish).

Nowak J., 2000. The effect of different preparation containing gibberellic acid on the growth and flowering of cyklamen and gerbera. Zesz. Nauk. ISiK, Skierniewice, 7: 259-263 (in Polish).

Nowak J., Rudn icki R. M., 1993. Hyacinthus. Chapter 24 in "The physiology of flower bulbs”. A. de Hertogh, 
M. le Nard (ed.) Amsterdam-London-New York-Tokyo: 335-347.

Saniewski M., Puchalski J., 1977. The effect of gibberellic acid on bulblet differentiation and electrophoretic patterns of peroxidase in scooped out hyacinth bulbs. Plant Growth Regulators, Proc. Int. Symp. Sofia: 169-172.

Saniewski M., Tymoszczuk J., Rudnicki R. M., 1978. Hormonal control of flowering and the growth of the inflorescence stalk and leaves of Muscari armeniacum Leichtl. Prace ISiK, Skierniewice, seria B, tom 3: 57-67.

Treder J., 2003a. Calla lilies with colourful spathes. Hortpress Sp. z o.o., Warszawa: 32 (in Polish).

Tre de r J., 2003b. Growth and flowering of Zantedeschia cultivated in a greenhouse or in open field. Zesz. Probl. Post. Nauk Roln. 491: 283-291 (in Polish).

Treder J., Matysiak B., Nowak J., 1999. The effect of gibberellic acid on growth and flowering of Cyclamen persicum Mill.. Folia Hortic. 11 (2): 81-86.
Wpływ opryskiwania kłączy i ich moczenia w kwasie giberelinowym na wzrost i kwitnienie cantedeskii (Zantedeschia Spreng.)

\section{Streszczenie}

Kłącza o obwodzie $15-18 \mathrm{~cm}$ z zawiązkami liści o długości $0,5-1 \mathrm{~cm}$ posadzono 15 maja 2006 roku do doniczek o średnicy $20 \mathrm{~cm}$, w podłoże składające się $\mathrm{z}$ substratu torfowego o $\mathrm{pH}$ 6,2, wzbogaconego nawozem o spowolnionym działaniu Osmocote Plus (3-4M) i zmieszanego ze świeżą, rozdrobnioną korą sosnową w stosunku objętościowym 3:1 (v:v). Przed sadzeniem kłącza moczono przez 20 minut w wodnym roztworze kwasu giberelinowego o stężeniu $150 \mathrm{mg} \times \mathrm{dm}^{-3}$ lub opryskiwano tym samym stężeniem kłącza jeden, dwa lub trzy razy, każdorazowo po dokładnym ich obeschnięciu. Przy każdym opryskiwaniu zużywano 100 $\mathrm{ml}$ roztworu. Zastosowano Gibrescol 10 MG. Kwas giberelinowy zastosowany $\mathrm{w}$ formie roztworu do moczenia kłączy lub ich opryskiwania zadziałał w podobny sposób. Liczba zabiegów opryskiwania kłączy nie miała wpływu na efektywność działania kwasu giberelinowego. U odmiany Black Magic opryskiwanie kłączy miało podobny wpływ na wcześniejsze kwitnienie, natomiast u odmiany Cameo podobny efekt uzyskano mocząc kłącza w kwasie giberelinowym. Kwas giberelinowy nie wywarł wpływu na jakość kwiatów i liczbę liści. Kwas giberelinowy wywarł korzystny wpływ na indeks zazielenienia liści badanych odmian. 